Małgorzata Mędrala (i) https://orcid.org/0000-0002-0068-2975

Uniwersytet Ekonomiczny w Krakowie

\title{
WYNAGRODZENIE PRACOWNIKA W OKRESIE PRZESTOJU Z POWODU SIŁY WYŻSZEJ
}

\author{
Abstract \\ The employee's remuneration for the period of non-performance of work \\ because of force majeure
}

The paper presents the issue of the employee's right to remuneration for the period of nonperformance of work because of force majeure. The Author analyzes if the employee has the right to receive the remuneration in this case, and if the answer for this question is positive-what its legal nature is (is it a contractual remuneration for work or a social benefit to the employee within the employment relationship). The Author underlines the lack of clear regulations in these matters in Polish law, with the exception of the specific regulations concerning the periods of interruption caused by adverse weather conditions.

Słowa kluczowe: pracodawca, pracownik, ryzyko pracodawcy, przestój, wynagrodzenie

Keywords: employer, employee, employer's risk, force majeure, remuneration

ASJC: 3308, JEL: K31

\section{Ryzyko techniczne a ryzyko socjalne pracodawcy}

Cechą definicyjną stosunku pracy jest zobowiązanie pracownika do wykonywania pracy określonego rodzaju na rzecz pracodawcy i pod jego kierownictwem oraz w miejscu i czasie wyznaczonymi przez niego, a w zamian - zobowiązanie pracodawcy do zatrudniania pracownika za wynagrodzeniem (art. $22 \$ 1$ ustawy z dnia 26 czerwca 1974 roku - Kodeks pracy, Dz.U. 2019, poz. 1040 tekst jedn. ze zm., dalej: Kodeks pracy, k.p.). Wynagrodzenie za pracę jest zatem podstawowym świadczeniem ze stosunku pracy, gwarantującym jego główną funkcję jako źródła utrzymania dla pracownika i jego rodziny (Nowak 2007, s. 43; Goździewicz 2009, s. 65). Zasadą jest przy tym, iż wynagrodzenie przysługuje za pracę wykonaną. Za czas niewykonywania pracy pracownik zachowuje prawo do wynagrodzenia tylko wówczas, gdy przepisy prawa pracy tak stanowią (art. 80 k.p.). 
Jednocześnie Kodeks pracy przewiduje wiele sytuacji, w których pracodawca zobowiązany jest wypłacać pracownikowi wynagrodzenie za pracę pomimo braku świadczenia wzajemnego i ekwiwalentnego. Chodzi o okresy niewykonywania pracy lub wykonywania pracy o niższej niż zakładana wartości z zachowaniem całości lub części wynagrodzenia za pracę przez pracownika. W doktrynie prawa pracy najczęściej sytuacje te określa się mianem ryzyka pracodawcy (Lewandowicz-Machnikowska 2019, s. 181-183). Mówi się nawet o ryzyku pracodawcy jako podstawowej zasadzie prawa pracy (Walczak 2020, art. 81 k.p., teza A.1). Łukasz Pisarczyk (2008, s. 28 i 33) w swojej monografii poświęconej temu zagadnieniu wskazuje, iż ryzyko wystąpienia okoliczności niepożądanych z punktu widzenia stosunku pracy można rozpatrywać w płaszczyźnie faktycznej, prawnej i normatywnej. Z punktu widzenia odpowiedzialności pracodawcy za skutki tego ryzyka analizy wymaga przede wszystkim ryzyko normatywne, rozumiane jako „sposób ukształtowania prawnych konsekwencji wystąpienia niepożądanych zdarzeń" (Pisarczyk 2008, s. 33).

W doktrynie prawa pracy wyróżnia się najczęściej cztery rodzaje ryzyka pracodawcy:

- ryzyko ekonomiczne (gospodarcze),

- ryzyko techniczne,

- ryzyko osobowe,

- ryzyko socjalne (Pisarczyk 2008, s. 28; Lewandowicz-Machnikowska 2019, s. 181). Łukasz Pisarczyk zwraca uwage, że ryzyko techniczne i osobowe bywają ujmowane łącznie jako ryzyko produkcyjne (Pisarczyk 2008, s. 28).

$\mathrm{W}$ prowadzonych przez siebie do tej pory badaniach naukowych prezentuję stanowisko, iż w przypadku tak zwanego ryzyka socjalnego sprowadzającego się do narzuconych ustawowo na podmioty będące pracodawcami obowiązków wypłaty pracownikom świadczeń pieniężnych w miejsce wynagrodzenia za pracę mamy do czynienia z tak zwanymi świadczeniami społecznymi w ramach stosunku pracy. Ich istotą jest, że przysługują one pracownikowi, mimo iż nie świadczy on pracy ze względu na usprawiedliwione ze względów społecznych, a zwłaszcza socjalnych przyczyny (takie jak na przykład choroba, potrzeba odpoczynku, odgrywanie ról społecznych, w tym związanych $\mathrm{z}$ rodzicielstwem) lub też z tych powodów świadczy pracę o wartości niższej niż świadczenie wzajemne pracodawcy (na przykład kobieta w ciąży, którą pracodawca ze względu na przepisy BHP zobowiązany jest przenieść do innej pracy). Do takich świadczeń ze stosunku pracy zaliczam między innymi wynagrodzenie urlopowe, chorobowe, ustawowe odprawy związane z rozwiązaniem stosunku pracy (z przyczyn niedotyczących pracownika, pośmiertne, emerytalno-rentowe), świadczenia pomocowe z zakładowych funduszy świadczeń socjalnych, dodatek wyrównawczy do minimalnego wynagrodzenia za pracę oraz dodatki wyrównawcze dla kobiet w ciąży lub matek karmiących piersią w przypadku ustawowych zakazów wykonywania umówionej pracy (art. 1781, 179 k.p.). Wykazują one, moim zdaniem, cechy tak zwanych transferów społecznych (niewzajemność, obligatoryjność, społeczne przeznaczenie, solidarnościowy charakter, odzwierciedlenie w socjalnych prawach człowieka) i są instrumentami polityki społecznej państwa (Mędrala 2020, passim). Dlatego też w ich przypadku można 
mówić o narzuceniu przez państwo na pracodawców publicznoprawnych obowiązków ponoszenia kosztów społecznych, w tym w szczególności socjalnych w stosunku do pracowników (Żołyński 2018, s. 37).

Niniejszy tekst poświęcony zostanie natomiast zagadnieniu ryzyka pracodawcy w przypadku przestoju z art. 81 k.p. w sytuacji wystąpienia tak zwanej siły wyższej. Zgadzam się przy tym z utrwalonymi w doktrynie poglądami, że sam przestój i będący jego konsekwencją obowiązek wypłaty gwarancyjnego wynagrodzenia przestojowego należy co do zasady traktować jako ryzyko techniczne (produkcyjne) pracodawcy (Pisarczyk 2008, s. 211 i n.; Żołyński 2018, s. 36), za które pracownik nie ponosi odpowiedzialności (wyrok Sądu Najwyższego z dnia 3 czerwca 1998 roku, I PKN 49/98, OSNAPiUS 1999, nr 11, poz. 362). Nie można w tym przypadku mówić o świadczeniach społecznych, albowiem jest to faktycznie ryzyko związane z prowadzeniem określonej działalności przez pracodawcę, $\mathrm{z}$ którym $\mathrm{w}$ ramach wykonania zobowiązania powinien się liczyć. Niemniej jednak instytucja przestoju nie pozostaje do końca konstrukcją jednolitą, czego wyrazem jest właśnie sytuacja przestoju, u źródła którego leżą zdarzenia o charakterze siły wyższej, na które pracodawca nie ma żadnego wpływu i których w normalnych warunkach nie musi w swoim ryzyku prowadzonej działalności uwzględniać. Ciekawe są wśród nich zwłaszcza przypadki, gdy siła wyższa prowadzi do niemożności wykonania zobowiązania zarówno przez pracodawcę, jak i do wątpliwej możliwości jego wykonania przez pracownika. Kwestia ta stała się szczególnie aktualna w czasie trwającej pandemii spowodowanej rozprzestrzenianiem się wirusa SARS-Cov-2 (koronawirusa). Przypomnijmy, iż na skutek rozwoju zagrożenia epidemiologicznego w całym kraju zostały wprowadzone ograniczenia w zakresie funkcjonowania określonych instytucji i zakładów pracy (rozdział 4 rozporządzenia Ministra Zdrowia z dnia 13 marca 2020 roku w sprawie ogłoszenia na obszarze Rzeczypospolitej Polskiej stanu zagrożenia epidemicznego, Dz.U. 2020, poz. 433; rozdział 4 rozporządzenia Ministra Zdrowia w sprawie ogłoszenia na obszarze Rzeczypospolitej Polskiej stanu epidemii z dnia 20 marca 2020 roku, Dz.U. 2020, poz. 491). Na mocy rozporządzeń Ministra Zdrowia w sprawie ogłoszenia stanu zagrożenia epidemicznego i stanu epidemii wprowadzono między innymi całkowity zakaz prowadzenia wymienionych w przepisach rodzajów działalności. Ograniczenia te ustanowione zostały w związku z zakażeniami wirusem SARS-Cov-2 ( $\$ 1$ obu wymienionych rozporządzeń). Niemniej jednak rozważania nad świadczeniami przysługującymi pracownikowi od pracodawcy w tym zakresie mają także znaczenie w przypadku innych tego rodzaju sytuacji powstałych na skutek wystąpienia siły wyższej, a zdarzających się w praktyce funkcjonowania zakładów pracy. Celowo przy tym używam zwrotu „świadczenie”, albowiem wynagrodzenie jest również świadczeniem, a obok wynagrodzenia za pracę pracownikowi przysługują także „inne świadczenia związane z pracą" (art. $77^{1}$ k.p.; Tomaszewska 2016, s. 324-325; Mędrala 2020, s. 116-119, 139-145), z których część ma charakter społeczny.

Zaznaczam przy tym, iż pojawiająca się ostatnio kwestia wynagrodzenia i jego charakteru dla pracowników w okresie zamknięcia zakładu pracy na skutek odgórnego nakazu administracyjnego nie jest jedynym przykładem braku w polskim prawie pracy 
szczególnych regulacji w zakresie prawa do wynagrodzenia za pracę pracownika czy innych świadczeń związanych z pracą w przypadku wystąpienia przestoju na skutek tak zwanej siły wyższej. Jest to jednak doskonała okazja do poruszenia omawianej tematyki. Szczególnie interesującym zagadnieniem w tej sytuacji pozostaje bowiem kwestia prawa do wynagrodzenia pracownika, gdy brak możliwości wykonania zobowiązania nie wynika jedynie z przyczyn leżących po stronie pracodawcy (jak to jest w przypadku klasycznych przypadków przestojów), ale jednocześnie gdy przyczyna ta występuje także po stronie pracownika. Pracownik ze względu na aktualną sytuację krajową, meteorologiczną, logistyczną itp. nie jest bowiem w stanie wykonywać pracy, a jednocześnie pracodawca $z$ tych samych powodów nie jest w stanie mu tej pracy zapewnić. Można więc twierdzić, iż przyczyna niewykonania zobowiązania leży po obu stronach. W takim przypadku powstaje pytanie o ewentualne świadczenie przysługujące pracownikowi od pracodawcy za ten okres, o jego podstawy oraz charakter prawny. Jeżeliby nawet przyjąć, iż pracownikowi w takim przypadku przysługuje wynagrodzenie przestojowe, to - moim zdaniem - istnieją duże wątpliwości, czy rozpatrywać go w kategorii ryzyka pracodawcy, czy też raczej świadczenia społecznego. Ponadto można sformułować argumenty aksjologiczne za tym, by sam przestój powstały na skutek siły wyższej traktować odmiennie od pozostałych przypadków przestojów.

\section{Cechy przestoju oraz charakter wynagrodzenia przestojowego a przestój z powodu siły wyższej}

Szczegółową analizę zacznijmy od samego pojęcia przestoju oraz regulacji kodeksowych w tym zakresie. Kodeks pracy nie definiuje pojęcia przestoju. Z przepisów art. 81 $\$ 1-2$ k.p. wynika, że chodzi w tym przypadku o sytuację niewykonywania pracy przez pracownika z przyczyn dotyczących pracodawcy, a niezawinionych przez pracownika, przy jednoczesnym wykazywaniu przez pracownika gotowości do jej wykonywania.

W orzecznictwie wskazuje się, iż z treści art. 81 k.p. wynikają dwie podstawowe przesłanki do nabycia prawa do wynagrodzenia przestojowego:

a) gotowość pracownika do wykonywania pracy,

b) doznanie przeszkód w wykonywaniu pracy z przyczyn leżących po stronie pracodawcy (wyrok Sądu Najwyższego z dnia 23 października 2006 roku, I PK 110/06, Legalis nr 79155, teza 2).

Ustawodawca słusznie dostrzega przy tym wpływ zawinionych zachowań pracownika na zjawisko przestoju. Zgodnie z art. $81 \S 2$ k.p. wynagrodzenie przestojowe przysługuje pracownikowi za czas niezawinionego przez niego przestoju. Jeżeli przestój nastąpił z winy pracownika, wynagrodzenie nie przysługuje (wyrok Sądu Najwyższego z dnia 3 czerwca 1998 roku, I PKN 49/98, OSNAPiUS 1999, nr 11, poz. 362).

W sytuacjach klasycznych przypadków przestoju z art. 81 k.p. pracownikowi przysługuje wynagrodzenie wynikające $\mathrm{z}$ jego osobistego zaszeregowania, określonego stawką godzinową lub miesięczną, a jeżeli taki składnik wynagrodzenia nie został 
wyodrębniony przy określaniu warunków wynagradzania - 60\% wynagrodzenia. Wynagrodzenie to nie może być jednak niższe od minimalnego wynagrodzenia za pracę, ustalanego na podstawie odrębnych przepisów (art. $81 \$ 1$ k.p.). Tego typu regulacja stanowi więc pewne ograniczenie ryzyka pracodawcy. Ryzyko pracodawcy w takich przypadkach jest zarazem mniejsze niż w przypadku umów cywilnoprawnych, w ramach których w sytuacji przestoju, z wyjątkiem przestoju spowodowanego siłą wyższą, zleceniodawca/zamawiający w pełni odpowiada za brak świadczenia wzajemnego (np. art. 639 k.c.). Świadczy to zatem o dostrzeganiu przez ustawodawcę potrzeby ochrony interesów pracodawcy w takich sytuacjach i jest wyrazem pewnej solidarności wspólnotowej na poziomie zakładu pracy. Z tego punktu widzenia sytuacja osób zatrudnionych na umowach cywilnoprawnych przy zwykłym przestoju jest więc korzystniejsza. Jeśli jednak będziemy mieć na uwadze całokształt innych świadczeń o charakterze społecznym, które im nie przysługują (w przeciwieństwie do pracowników), zatrudnienie pracownicze i tak prezentuje się jako korzystniejsze (Mędrala 2020, s. 466). W doktrynie w tym kontekście spotkać można także poglądy o potrzebie wprowadzenia zasady pełnego wynagrodzenia za czas nieświadczenia pracy, które będzie uwzględniać przeciętny dochód pracownika z okresu poprzedzającego wystąpienie przeszkody ( $\mathrm{Pi}$ sarczyk 2008, s. 235; por. Skoczyński 2009, s. 279). Poglądy te uważam jednak za zbyt daleko idące. Istnieją, moim zdaniem, argumenty uzasadniające ograniczenie ryzyka pracodawcy w przypadku przestoju w imię ogólnej zasady solidarności w stosunkach pracy (Mędrala 2020, s. 466).

Mając na uwadze powyższe cechy przestoju, w standardowym ujęciu należałoby przeanalizować wskazane przesłanki w kontekście przestoju powstałego na skutek zjawiska siły wyższej. W doktrynie występuje przy tym na ogół pogląd, iż wynagrodzenie przestojowe należy się pracownikowi także wtedy, gdy przestój nastąpił z powodu siły wyższej (Skoczyński 2005, art. 81 k.p., teza 1; Pisarczyk 2008, s. 29 i cytowana tam pozycja Święcickiego 1968; a także: Pisarczyk 2008, s. 230-231). Ustawodawca jednocześnie nie definiuje ani pojęcia siły wyższej, ani pojęcia przestoju. Pojęcie siły wyższej najczęściej występuje na gruncie prawa cywilnego. W orzecznictwie polskich sądów za dominującą uznaje się obiektywną koncepcję siły wyższej. Do zdarzeń objętych kategorią siły wyższej zalicza się „zdarzenia zewnętrzne w stosunku do przedsiębiorstwa, którego działalność jest rozpatrywana jako przyczyna szkody”. Jako cechy charakterystyczne siły wyższej wskazuje się: nieuchronność, nadzwyczajność i niemożliwość przewidzenia (uzasadnienie uchwały Sądu Najwyższego z dnia 13 grudnia 2007 roku, III CZP 100/07, OSNC 2008, nr 12, poz. 139). Zdarzenia o charakterze siły wyższej Sąd Najwyższy ujmuje w trzy grupy:

- klęski żywiołowe (vis naturalis), na przykład „powódź, uderzenie pioruna, burza o ogromnej sile, huragan, obfite opady śniegu, nieprzenikniona mgła";

- działania zbrojne (vis armata), na przykład „działania sił zbrojnych wrogiego państwa, rozruchy, rebelie, wojny domowe, akty piraterii, napaść zbrojnej bandy”,

- akty władzy (vis imperii), na przykład „akty normatywne zakazujące wwozu określonych towarów, decyzje administracyjne o zniszczeniu ładunku ze względów 
sanitarnych, orzeczenia sądu o konfiskacie ładunku, błędny sygnał policjanta kierującego ruchem drogowym" (uzasadnienie uchwały Sądu Najwyższego z dnia 13 grudnia 2007 roku, III CZP 100/07, OSNC 2008, nr 12, poz. 139).

W doktrynie prawa cywilnego wprowadzenie nowych, niemożliwych do przewidzenia i niestosowanych w prawidłowo funkcjonujących społeczeństwach zakazów prawnych związanych z jakąś szczególną sytuacją uznaje się za nadzwyczajną zmianę stosunków (Machnikowski 2019, art. $357^{1}$ k.p., teza II. 2). Zdaniem Sądu Najwyższego jako nadzwyczajna zmiana stosunków mogą być kwalifikowane między innymi zasadnicze i zaskakujące zmiany stawek celnych i podatkowych (teza wyroku Sądu Najwyższego z dnia 17 stycznia 2008 roku, III CSK 202/07, Legalis nr 127040; podobnie wyroki Sądu Najwyższego: z dnia 16 maja 2007 roku, III CSK 452/06, OSP 2009, nr 2, poz. 19, z glosą: Lackoroński 2009, oraz z dnia 20 lipca 2007 roku, I CK 3/07, OSNC-ZD 2008, $\mathrm{nr} 3$, poz. 65). Z tej perspektywy ogłoszona w dniu 11 marca 2020 roku przez dyrektora generalnego WHO na konferencji prasowej w Genewie pandemia wirusa SARS-Cov-2 może być traktowana jako siła wyższa o charakterze vis naturalis.

Przepisy ustawy z dnia 23 kwietnia 1964 roku - Kodeks cywilny (Dz.U. 2019, poz. 1145 tekst jedn. ze zm., dalej: k.c.; art.: 357², 471 i 495 k.c.) przewidują jednocześnie możliwość uwolnienia się od zobowiązania na skutek wystąpienia siły wyższej lub nadzwyczajnej zmiany okoliczności. Przepis art. 471 k.c. stanowi, że „dłużnik jest zobowiązany do naprawienia szkody wynikłej z niespełnienia ciążącego na nim świadczenia, z wyjątkiem sytuacji gdy przyczyną jego niespełnienia była okoliczność, za którą nie ponosi on odpowiedzialności”. Przepis art. $357^{1}$ k.c. pozwala $\mathrm{z}$ kolei „w przypadku wystąpienia nadzwyczajnej zmiany stosunków, w której spełnienie świadczenia byłoby połączone z nadmiernymi trudnościami albo groziłoby jednej ze stron rażącą stratą, czego strony nie przewidywały przy zawarciu umowy", na sądową zmianę wykonania zobowiązania, wysokości świadczenia lub nawet na orzeczenie o rozwiązaniu umowy. Podobnie w przypadku zobowiązań wzajemnych obowiązuje zasada, zgodnie z którą (art. 495 k.c.):

Jeżeli jedno ze świadczeń wzajemnych stało się niemożliwe wskutek okoliczności, za które żadna ze stron odpowiedzialności nie ponosi, strona, która miała to świadczenie spełnić, nie może żądać świadczenia wzajemnego, a w wypadku, gdy je już otrzymała, obowiązana jest do zwrotu według przepisów o bezpodstawnym wzbogaceniu.

W prawie pracy ustawodawca takich rozwiązań nie przewiduje, co w konsekwencji pozostawia do rozważenia trzy możliwe podejścia do świadczeń / wynagrodzenia pracownika w okresie przestoju powstałego na skutek siły wyższej:

1) mamy do czynienia $z$ wynagrodzeniem przestojowym $z$ art. 81 k.p., które należy rozpatrywać w kategorii ryzyka pracodawcy,

2) mamy do czynienia ze świadczeniem społecznym wypłacanym przez pracodawcę na rzecz pracownika, albowiem przestój spowodowany siłą wyższą wykracza poza ryzyko pracodawcy, 
3) wynagrodzenie ani żadne inne świadczenia związane z pracę nie przysługują w takich sytuacjach w ogóle (dotyczy to zwłaszcza przypadków, gdy wykazanie gotowości do wykonywania pracy przez pracownika pozostaje wątpliwe), chyba że występuje przepis szczególny w tej materii.

\section{Przesłanka „przyczyn leżących po stronie pracodawcy” w świetle art. $81 \S 1$ k.p. a przestój z powodu siły wyższej}

Nie ulega raczej wątpliwości, iż w przypadku przestoju spowodowanego siłą wyższą występuje brak winy pracownika, podobnie jak przy przestoju w tradycyjnej sytuacji. Dlatego też pogłębionej analizy wymagają przesłanki „przyczyn leżących po stronie pracodawcy” oraz "gotowości pracownika do pracy”.

Zacznijmy od pierwszej z nich. Według Słownika języka polskiego PWN przestój to „przerwa w pracy, w produkcji itp., wynikła na przykład z powodu awarii maszyn lub złej organizacji pracy”. Według Barbary Wagner „przestój jest nieplanowaną, przejściową, aczkolwiek nieograniczoną czasowo przerwą w wykonywaniu pracy, spowodowaną zaburzeniami w funkcjonowaniu zakładu pracy powstałymi wskutek niedających się przewidzieć okoliczności”. Autorka wskazuje na przyczyny przestoju natury technicznej lub organizacyjnej (Wagner 2017, art. 81 k.p., teza 17). Jako przyczyny przestoju wymienia się zakłócenia w postaci braku materiału, narzędzi (Muszalski 2019, art. 81 k.p., teza 1), braku dostaw energii, awarii urządzeń technicznych, problemy z transmisją danych, przepływem informacji (Pisarczyk 2008, s. 207). Według części przedstawicieli nauki prawa pracy w pojęciu przestoju zawiera się element zaskoczenia, nietypowości i wyjątkowości (Muszalski 2019, art. 81 k.p., teza 1; uzasadnienie uchwały Sądu Najwyższego z dnia 16 października 1992 roku, I PZP 58/92, OSNCP 1993, nr 6, poz. 95; por. także analizę uzasadnienia wskazanej uchwały: Skoczyński 2009, s. 269-271).

Przyczyny dotyczące pracodawcy ujmuje się bardzo szeroko. Wojciech Muszalski wskazuje na wszelkie przyczyny, zarówno zawinione, jak i niezawinione przez niego, obiektywne oraz subiektywne (Muszalski 2019, art. 81 k.p., teza 1). Zdaniem Andrzeja M. Świątkowskiego jedynie zaistnienie przeszkód dotyczących wyłącznie pracownika wyklucza zastosowanie art. $81 \$ 1$ k.p. (Świątkowski 2018, art. 81 k.p., teza I.1). Przy takim ujęciu w ramach przestoju mieściłyby się więc także sytuacje o charakterze siły wyższej.

Jednocześnie przepisy Kodeksu pracy nie regulują jednoznacznie przypadków, gdy oprócz przyczyny „dotyczącej pracodawcy” występuje także przyczyna „dotycząca pracownika", bo za taką można uznać niektóre zdarzenia o charakterze siły wyższej. Innymi słowy, chodzi o sytuacje, gdy przyczyna leżąca u podstaw niemożności świadczenia pracy leży zarówno po stronie pracownika, jak i pracodawcy. Dobrym przykładem tego może być wspomniana na wstępie sytuacja epidemii wirusa SARS-Cov-2, która spowodowała zamknięcie w drodze administracyjnej licznych placówek zatrudnieniowych. 
W takiej sytuacji nie sposób mówić o przyczynie leżącej wyłącznie po stronie pracodawcy, ponieważ uzasadnione jest twierdzenie, że przyczyna ta występuje także po stronie pracownika. Ze względu na ochronę zdrowia i potencjalną możliwość zakażenia się koronawirusem pracownik nie może świadczyć pracy danego rodzaju i w danym miejscu. Jednocześnie jednak Kodeks pracy w art. 81 nie traktuje o przyczynie „niedotyczącej pracownika", jak to jest na przykład w przypadku zwolnień dokonywanych w trybie ustawy z dnia 13 marca 2003 roku o szczególnych zasadach rozwiązywania z pracownikami stosunków pracy z przyczyn niedotyczących pracowników (Dz.U. 2018, poz. 1969 tekst jedn.), ale wyłącznie o przyczynie dotyczącej pracodawcy. I dlatego też ostatecznie za uprawniony należy, moim zdaniem, uznać wniosek, iż przyczyną „dotyczącą pracodawcy" z art. 81 k.p. jest też przestój spowodowany siłą wyższą w takich sytuacjach, choć nie jest to zarazem przyczyna leżąca wyłącznie po stronie pracodawcy, gdyż leży ona także po stronie pracownika.

\section{Przesłanka „gotowości do wykonywania pracy” przez pracownika w świetle art. 81 § 1 k.p. a przestój z powodu siły wyższej}

Przejdźmy zatem do analizy drugiej ze wskazanych przesłanek kodeksowych, a mianowicie przesłanki pozostawania przez pracownika w gotowości do wykonywania pracy w przypadku zaistnienia zjawiska siły wyższej, która powoduje niemożność świadczenia dotychczasowej pracy. Zgodnie ze Słownikiem języka polskiego $P W N$ „gotowość” to „1. «stan pogotowia», 2. «stan należytego przygotowania do czegoś», 3. «zdecydowanie się na coś»”.

W orzecznictwie wskazuje się, iż cechami charakterystycznymi gotowości pracownika do wykonywania pracy są:

1) zamiar wykonywania pracy,

2) faktyczna zdolność do świadczenia pracy,

3) uzewnętrznienie gotowości do wykonywania pracy,

4) pozostawanie w dyspozycji pracodawcy (uzasadnienie wyroku Sądu Najwyższego z dnia 14 grudnia 2009 roku, I PK 115/09, Legalis nr 244007; zob. także wyroki Sądu Najwyższego: z dnia 2 września 2003 roku, I PK 345/02, OSNP 2004, nr 18, poz. 308; z dnia 23 września 2004 roku, I PK 541/03, OSNP 2005, nr 7, poz. 94; z dnia 11 stycznia 2006 roku, II PK 111/05, OSNP 2006, nr 23-24, poz. 347).

Jak wskazał Sąd Najwyższy w wyroku z dnia 26 czerwca 1998 roku, I PKN 195/98 (OSNAPiUS 1999, nr 14, poz. 453):

[...] gotowość do pracy w rozumieniu art. $81 \$ 2$ k.p. występuje jedynie podczas istnienia wiążącego strony stosunku pracy, w razie powstania przeszkód z przyczyn dotyczących pracodawcy w określonym w umowie czasie i miejscu pracy, uniemożliwiających pracownikowi jej wykonywanie, gdy jednocześnie pozostaje on zgodnie z art. $128 \$ 1$ k.p. do dyspozycji pracodawcy w zakładzie pracy lub innym umówionym z nim miejscu. 
Jednocześnie Sąd Najwyższy wskazuje, że samo oczekiwanie przez pracownika na wezwanie go przez pracodawcę do wykonywania pracy może być traktowane jako gotowość do jej wykonywania tylko wtedy, gdy usprawiedliwiają to okoliczności sprawy (wyrok Sądu Najwyższego z dnia 14 maja 1999 roku, I PKN 60/99, OSNAPiUS 2000, $\mathrm{nr} 15$, poz. 5). I takie podejście akurat dałoby się obronić w przypadku siły wyższej, na skutek której zakład pracy został zamknięty.

Na uwagę zasługuje także stanowisko orzecznicze, zgodnie z którym:

[...] przez faktyczną gotowość należy rozumieć stan, w którym pracownik jest fizycznie i psychicznie zdolny do wykonywania pracy, w tym, że nie występują przeszkody do jej świadczenia na przykład w postaci niezdolności do pracy spowodowanej chorobą lub innymi przyczynami (wyrok Sądu Najwyższego z dnia 19 maja 2004 roku, I PK 486/03, Legalis nr 67895).

Powyższe stwierdzenie pozostaje bardzo istotne w kontekście zamknięcia zakładu pracy na mocy decyzji administracyjnej spowodowanej na przykład epidemią. $Z$ tej perspektywy można bowiem zadać pytanie, czy pracownik w czasie epidemii jest faktycznie zdolny do pracy. Do obrony jest bowiem, moim zdaniem, także stanowisko, iż w takim przypadku ta niemożność świadczenia pracy dotyczy również samego pracownika. To państwo ze względu na potencjalne zagrożenia zdrowotne dla pracownika i innych osób decyduje o braku możliwości świadczenia danego rodzaju pracy na danym terenie. Tym samym zakaz świadczenia określonej pracy odbywa się w imię ochrony życia i zdrowia ludzkiego, w tym pracownika. Dlatego też - moim zdaniem - w tym przypadku spełnianie przez pracownika przesłanki gotowości do wykonywania pracy pozostaje wysoce kontrowersyjne ze względu na wątpliwości co do jego zdrowotnej możliwości świadczenia pracy w określonych warunkach. Podobnie zresztą w wyroku z dnia 2 września 2003 roku, I PK 345/02 (OSNP 2004 nr 18, poz. 308), Sąd Najwyższy stwierdził, iż „przez pozostawanie w dyspozycji pracodawcy jako element gotowości do pracy w rozumieniu art. $81 \S 1$ k.p. należy rozumieć stan, w którym pracownik może niezwłocznie na wezwanie pracodawcy podjąć pracę" (zob. także uzasadnienia wyroków Sądu Najwyższego: z dnia 4 grudnia 2003 roku, I PK 109/03, OSNP 2004, nr 21, poz. 367; z dnia 11 stycznia 2006 roku, II PK 111/05, OSNP 2006, nr 23-24, poz. 347). W rozważanych przypadkach przestoju zakładu pracy na skutek siły wyższej sytuacja taka jednak nie występuje z powodu niezdolności pracownika do podjęcia pracy ze względu na ustawowy zakaz jej wykonywania. Inną sprawą jest to, że pracodawca nie jest w stanie skutecznie wezwać pracownika do wykonywania pracy. Z drugiej strony samo bierne oczekiwanie na wezwanie pracodawcy do świadczenia pracy nie uzasadnia wypłaty wynagrodzenia $\mathrm{z}$ art. $81 \mathrm{k} . \mathrm{p}$.

Nie można także w tym kontekście zapominać, iż prawo do wynagrodzenia przestojowego stanowi wyjątek od zasady, że wynagrodzenie za pracę powinno przysługiwać za pracę wykonaną (art. 80 k.p.). Wyjątki zaś powinny być wykładane ściśle. W orzecznictwie zwrócono w tym kontekście uwagę także na to, iż wykładnia art. $81 \$ 1$ k.p. powinna uwzględniać interesy zarówno pracodawcy, jak i pracownika (wyrok Sądu Najwyższego 
z dnia 3 lutego 2016 roku, II PK 339/14, Legalis nr 1421831, teza 2). Dlatego też powyższe można skonkludować stwierdzeniem, że istnieją argumenty przemawiające za tezą, iż w przypadku przestoju w pracy zaistniałego na skutek siły wyższej pracownik nie zawsze spełnia przesłankę "gotowości do wykonywania pracy” lub spełnianie przez niego tej przesłanki pozostaje w niektórych przypadkach co najmniej wątpliwe. Można oczywiście wyobrazić sobie także sytuację, gdy zjawiskiem siły wyższej zostanie dotknięty tylko pracodawca, a pracownik będzie w stanie wykazać gotowość do jej wykonywania, na przykład pożar części zakładu pracy. W wielu przypadkach w takich sytuacjach niemożność wypełniania obowiązków ze stosunku pracy dotyczy jednak obu stron, czego najlepszym przykładem jest właśnie ostatni administracyjny zakaz prowadzenia niektórych rodzajów działalności ze względu na ryzyko zakażeń koronawirusem. Ponadto można mieć poważne wątpliwości, czy przestój spowodowany siłą wyższą, zwłaszcza na dużą skalę, rzeczywiście powinien mieścić się w kategorii ryzyka pracodawcy ze względu na nadzwyczajny i nieprzewidywalny charakter takiego przestoju.

\section{Regulacje szczególne dotyczące przestoju spowodowanego siłą wyższą}

Przepisy polskiego prawa pracy nie regulują w sposób całościowy zagadnienia niemożności świadczenia pracy na skutek siły wyższej. Szczególne uregulowania ustawodawca przewidział tylko do prac związanych $\mathrm{z}$ warunkami atmosferycznymi oraz w sytuacji powodzi. W pierwszym przypadku Kodeks pracy nie przewiduje gwarancji wypłaty wynagrodzenia przestojowego, wprowadzając jednak możliwość odmiennego uregulowania tej kwestii na poziomie prawa zakładowego (art. $81 \S 4$ k.p.). W przepisach wewnątrzzakładowych, na przykład w regulaminach wynagradzania czy układach zbiorowych, możliwe jest zamieszczenie postanowień, które przewidują wypłatę określonego świadczenia w przypadku niemożności wykonywania pracy z powodu warunków atmosferycznych, na przykład w budownictwie w okresie zimowym czy przy żniwach podczas obfitych opadów. Takie postanowienia traktuje się wtedy jako korzystniejsze dla pracowników (Muszalski 2019, art. 81 k.p., teza 4). Jednocześnie istnienie odrębnych regulacji w tym zakresie może uzasadniać wniosek, iż w pozostałych przypadkach przestoju, nawet o charakterze siły wyższej, obowiązują ogólne zasady wypłaty wynagrodzenia przestojowego z art. 81 k.p., co może wydawać się nieproporcjonalnym obciążeniem pracodawców.

Pewne rozwiązania szczególne ustawodawca przewidział także w przypadku powodzi. Ich wprowadzenie zostało zresztą uwarunkowane kontekstem historycznym związanym z sytuacją powodzi w kraju i jej skutków. Pierwsza regulacja w tym zakresie pojawiła się w lipcu 1997 roku w związku z tak zwaną powodzią tysiąclecia (Skotnicka 2012, s. 2126). Tę regulację wprowadziła ustawa $z$ dnia 17 lipca 1997 roku o stosowaniu szczególnych rozwiązań w związku z likwidacją skutków powodzi, która miała miejsce w lipcu 1997 roku (Dz.U. 1997, nr 80, poz. 491 ze zm., dalej: s.s.r.z.l.s.p.). Na podstawie art. 4 
ust. 1 tej ustawy jako przyczyna usprawiedliwiającą nieobecność pracownika w pracy została potraktowana „faktyczna niemożność świadczenia pracy w związku z powodzią”. Za czas usprawiedliwionej nieobecności w pracy z tej przyczyny pracownik zachowywał prawo do odpowiedniej części wynagrodzenia określonego przez Ministra Pracy i Polityki Socjalnej na podstawie art. $77^{4}$ pkt 1 k.p. ${ }^{1}$ przez okres nie dłuższy niż pięć dni roboczych (art. 4 ust. 2 s.s.r.z.l.s.p.). Konstrukcja tego świadczenia wyraźnie przesądzała więc o tym, że w tym przypadku nie mieliśmy do czynienia $\mathrm{z}$ wynagrodzeniem przestojowym, a świadczeniem socjalnym. Świadczenie to można bowiem traktować jako świadczenie dla człowieka znajdującego się w potrzebie, narażonego na utratę źródła utrzymania w rezultacie określonej niespodziewanej sytuacji życiowej, zaistniałej na skutek wystąpienia zjawiska w postaci siły wyższej.

Na uwagę zasługuje w tym kontekście to, iż ustawodawca wyraźnie stwierdzał, że pracownik „zachowuje prawo do wynagrodzenia”. Taka konstrukcja oznaczała zarazem, że nie można było w tym przypadku mówić o wynagrodzeniu za pracę, ale o świadczeniu oderwanym od ryzyka pracodawcy, przysługującym w miejsce wynagrodzenia za pracę. O socjalnym charakterze tego świadczenia świadczył także wprowadzony ustawowo podział jego kosztów między pracodawcę a Fundusz Gwarantowanych Świadczeń Pracowniczych. W przypadku gdy pracodawca nie miał środków na pokrycie tego świadczenia ze względu na przejściowe zaprzestanie działalności wskutek powodzi, wynagrodzenie to wypłacane było ze środków Funduszu Gwarantowanych Świadczeń Pracowniczych. Decyzję o przyznaniu środków na wypłatę tego wynagrodzenia podejmował dyrektor wojewódzkiego urzędu pracy na podstawie pisemnego wniosku pracodawcy (art. 4 ust. $4-5$ s.s.r.z.l.s.p.). Pracodawca był więc wówczas pewnego rodzaju pośrednikiem w przyznaniu tego świadczenia.

Omawiana ustawa miała charakter jednorazowy. W roku 2011 ustawodawca zdecydował się zaś na kompleksową regulację świadczenia przysługującego pracownikowi za czas usprawiedliwionej nieobecności w pracy na skutek powodzi. W ustawie $\mathrm{z}$ dnia 16 września 2011 roku o szczególnych rozwiązaniach związanych z usuwaniem skutków powodzi (Dz.U. 2019, poz. 1317 tekst jedn. ze zm., dalej: s.r.z.u.s.p.) zawarto rozwiązanie, zgodnie z którym za czas usprawiedliwionej nieobecności w pracy wskutek powodzi pracownikowi przysługuje prawo do odpowiedniej części minimalnego wynagrodzenia za pracę, ustalanego na podstawie odrębnych przepisów, przez okres nie dłuższy niż dziesięć dni roboczych wynikających z rozkładu czasu pracy pracownika. Wynagrodzenie to wypłaca i ponosi jego koszty pracodawca (art. 8 ust. 2-4 s.r.z.u.s.p.). Ustawodawca nadaje więc temu świadczeniu pewne cechy konstrukcyjne świadczenia socjalnego. Przesłankami o charakterze socjalnym są ograniczenia co do wysokości świadczenia (do wysokości ustawowego minimalnego wynagrodzenia za pracę) oraz

1 Przepis skreślony ustawą z dnia 10 października 2002 roku o minimalnym wynagrodzeniu za pracę (Dz.U. 2002, nr 200, poz. 1679), która weszła w życie 1 stycznia 2003 roku. Chodziło o najniższe wynagrodzenie za pracę przysługujące pracownikom zatrudnionym w pełnym wymiarze czasu pracy, określane w drodze rozporządzenia przez Ministra Pracy i Polityki Socjalnej. 
wprowadzenie maksymalnego okresu jego wypłaty. Powyższe świadczy także o dostrzeżeniu przez ustawodawcę potrzeby proporcjonalności obciążeń pracodawców z tego tytułu (Mędrala 2020, s. 486-487). Nie mamy zatem przy tej konstrukcji do czynienia z wynagrodzeniem przestojowym, ale ze świadczeniem społecznym, którego koszty ponosi pracodawca. Pracodawca może także powierzyć pracownikowi wykonywanie pracy innego rodzaju niż wynikająca z nawiązanego stosunku pracy, jeżeli jest to konieczne w związku z usuwaniem skutków powodzi u tego pracodawcy. W takim przypadku pracownik już jednak zachowuje prawo do dotychczasowego wynagrodzenia, obliczonego według zasad obowiązujących przy obliczaniu wynagrodzenia za czas urlopu wypoczynkowego (art. 8 ust. 5 s.r.z.u.s.p.). Ponadto ustawa wyróżnia także sytuacje, gdy pracownik był gotów do wykonywania pracy, a doznał przeszkód z przyczyn dotyczących pracodawcy, które zostały bezpośrednio spowodowane powodzią (art. 23 ust. 1 pkt 2 s.r.z.u.s.p.). Ze względu na wykazywaną gotowość pracownika do wykonywania pracy ustawodawca traktuje te sytuacje jako przestój w ramach ryzyka pracodawcy, wprowadzając jednakże ustawową możliwość minimalizacji ich kosztów w postaci finansowej pomocy ze strony państwa² (Mędrala 2020, s. 487).

Powyższe regulacje, choć obecnie dość rzadko spotykane w praktyce, stanowią przykłady odmiennych regulacji sytuacji przestoju spowodowanego siłą wyższą. Może to budzić wątpliwości z perspektywy innych podobnych okoliczności, zwłaszcza o charakterze siły wyższej, kiedy pracownik nie jest w stanie wykazać swojej gotowości do pracy oraz kiedy również pracodawca nie może zapewnić mu pracy z tych samych powodów. De lege ferenda zasadne byłoby wprowadzenie analogicznych rozwiązań dla innych zbliżonych przypadków, nie tylko powiązanych ze zjawiskami przyrody, ale także zaistniałych w związku z nakazami administracyjnymi. Potrzeba takich regulacji uwidoczniła się ostatnio w szczególności w związku z pandemią wirusa SARS-Cov-2. W takich sytuacjach pracodawca nie ma bowiem wpływu na powstanie przeszkody, a pracownik nie może wykazać się pełną gotowością do świadczenia pracy. Ustawa z dnia

${ }^{2}$ Zgodnie z art. 23 ust. 1-2 s.r.z.u.s.p.: „W przypadku braku środków na wypłatę pracownikom wynagrodzenia przysługującego za: 1) czas usprawiedliwionej nieobecności w pracy w przypadku, o którym mowa w art. 8, 2) czas niewykonywania pracy, jeżeli pracownik był gotów do jej wykonywania, a doznał przeszkód z przyczyn dotyczących pracodawcy, które zostały bezpośrednio spowodowane powodzią, 3) wykonaną pracę, polegającą na ochronie zakładu pracy przed powodzią lub na usuwaniu skutków powodzi, mającą na celu utrzymanie lub przywrócenie prowadzenia przez pracodawcę działalności gospodarczej - pracodawca, który na skutek powodzi przejściowo zaprzestał prowadzenia działalności gospodarczej lub istotnie ograniczył jej prowadzenie, może złożyć do właściwego marszałka województwa wniosek o udzielenie nieoprocentowanej pożyczki z Funduszu Gwarantowanych Świadczeń Pracowniczych. Zaspokojeniu ze środków Funduszu Gwarantowanych Świadczeń Pracowniczych może podlegać ww. wynagrodzenie, miesięcznie do wysokości przeciętnego miesięcznego wynagrodzenia w gospodarce narodowej z poprzedniego kwartału ogłaszanego przez Prezesa Głównego Urzędu Statystycznego na podstawie przepisów o emeryturach i rentach z Funduszu Ubezpieczeń Społecznych, wraz ze składkami na ubezpieczenia społeczne należnymi od pracodawcy”. Pracodawca może także na warunkach ustawowych ubiegać się o umorzenie udzielonej pożyczki w przypadku wykazania określonego spadku dochodów (art. 23 ust. 6 s.r.z.u.s.p.). 
5 grudnia 2008 roku o zapobieganiu oraz zwalczaniu zakażeń i chorób zakaźnych u ludzi (Dz.U. 2019, poz. 1239 tekst jedn. ze zm.) nie przewiduje jednocześnie regulacji szczególnych w tym zakresie.

Dodatkowo na uwagę zasługuje w tym kontekście orzecznictwo Sądu Najwyższego dotyczące wpływu zamieci śnieżnej na niemożność stawienia się pracownika w miejscu pracy. W uchwale z dnia 19 czerwca 1979 roku, I PZP 20/79 (Legalis nr 212070) Sąd Najwyższy stwierdził, iż pracownikowi, który z powodu zamieci śnieżnej nie stawił się $\mathrm{w}$ pracy, nie przysługuje - w świetle art. $81 \$ 1$ k.p. - wynagrodzenie za czas niewykonywania pracy. W uzasadnieniu wyżej wymienionej uchwały Sąd Najwyższy wskazał, że:

Do uznania gotowości do pracy, o jakiej mowa w przepisie art. $81 \S 1$ k.p., niezbędna jest dyspozycyjność pracownika względem zakładu pracy. Oznacza ona, że pracownik powinien mieć możliwość niezwłocznego - na wezwanie zakładu pracy - przystąpienia do wykonywania pracy. W takiej sytuacji nie znajduje się pracownik, którego nie ma w siedzibie pracy i który pozostaje poza innym miejscem pracy ewentualnie wyznaczonym do jej wykonywania - z powodu niemożności dojazdu do miejsca pracy. Poza tym, obciążające zakład pracy, ryzyko niezapewnienia pracownikowi warunków koniecznych do świadczenia pracy nie obejmuje przeszkód w dowozie pracowników do pracy, również wówczas, gdy zakład pracy przyjął na siebie obowiązek zorganizowania przewozu pracowników do miejsc ich pracy. W tym wypadku nie chodzi o ryzyko związane $\mathrm{z}$ funkcjonowaniem zakładu pracy.

Tym samym w powyższym wyroku Sąd Najwyższy wyraził stanowisko, iż zjawiska o charakterze siły wyższej uniemożliwiające pracownikowi świadczenie pracy nie mogą być traktowane jako przestój z tego względu, że nie można wówczas mówić o ryzyku pracodawcy, ale de facto również - albo wyłącznie (w zależności od konkretnej sytuacji) - o ryzyku pracownika. Ponadto - co zasługuje na szczególne podkreślenie - Sąd przyjął, że w takim przypadku nie zostaje spełniona przesłanka gotowości pracownika do wykonywania pracy.

Dlatego też moim zdaniem trudno zgodzić się ze stanowiskiem prezentowanym przez Państwową Inspekcję Pracy (stanowisko Państwowej Inspekcji Pracy z 12 marca 2020 roku), w świetle którego „konieczność zamknięcia zakładu pracy w celu przeciwdziałania COVID-19 będzie przyczyną dotyczącą pracodawcy - mimo że będzie to przyczyna niezawiniona przez pracodawcę". Jako przykłady porównywalne Państwowa Inspekcja Pracy podaje odcięcie prądu w mieście, w tym również w zakładzie pracy, co uniemożliwia pracę, czy też powódź, która zalała zakład pracy. Tymczasem już w przypadku powodzi pracownik nie zawsze będzie w stanie dotrzeć do pracy, co może stanowić podstawę do usprawiedliwienia jego nieobecności w pracy i wypłaty ewentualnych świadczeń socjalnych $\mathrm{z}$ tego tytułu, o czym była mowa wcześniej, a nie do wypłaty wynagrodzenia przestojowego. W przypadku administracyjnego zakazu wykonywania określonej pracy ze względu na ryzyko zdrowotne przyczyna niemożności wykonywania pracy rozkłada się zaś po równo po obu stronach stosunku pracy. Dlatego też w konsekwencji nie można się do końca zgodzić ze stanowiskiem prezentowanym przez Państwową Inspekcję Pracy, że za okres niemożności świadczenia pracy 
w związku z taką sytuacją pracownikowi przysługuje wynagrodzenie ustalone według zasad wynikających $\mathrm{z}$ art. 81 k.p.

\section{Możliwość powstrzymania się od wykonywania pracy w trybie art. 210 k.p. a przestój z powodu siły wyższej}

Na koniec rozważenia wymaga także to, czy w sytuacjach przestoju na skutek wystąpienia siły wyższej można mówić o powstrzymaniu się przez pracownika od wykonywania pracy w warunkach zagrożenia życia lub zdrowia stwierdzonych przez właściwe podmioty państwowe, o czym traktuje regulacja $\mathrm{z}$ art. $210 \mathrm{k}$.p. Zgodnie $\mathrm{z}$ tym przepisem:

W razie gdy warunki pracy nie odpowiadają przepisom bezpieczeństwa i higieny pracy i stwarzają bezpośrednie zagrożenie dla zdrowia lub życia pracownika albo gdy wykonywana przez niego praca grozi takim niebezpieczeństwem innym osobom, pracownik ma prawo powstrzymać się od wykonywania pracy, zawiadamiając o tym niezwłocznie przełożonego. Za czas powstrzymania się od wykonywania pracy pracownik zachowuje prawo do wynagrodzenia.

Moim zdaniem regulacja ta $\mathrm{w}$ analizowanych przypadkach nie znajdzie jednak zastosowania z co najmniej dwóch powodów. Po pierwsze w omawianym przepisie chodzi o możliwość odmowy wykonywania pracy przez pracownika, a nie o obowiązek. W przypadku przestoju w zakładzie pracy na skutek siły wyższej (na przykład decyzji administracyjnej zakazującej działalności określonego rodzaju) pracownik w ogóle nie ma możliwości świadczenia pracy, taki wybór mu więc nie przysługuje. Po drugie - w tym przypadku nie mamy do czynienia z niebezpieczeństwem spowodowanym przyczynami występującymi w procesie pracy, ale z przyczynami zewnętrznymi. Pracownik nie tylko może, ale też musi powstrzymać się od wykonywania pracy ze względu na niektóre zakazy administracyjne lub inne okoliczności o charakterze vis maior. Tym samym nie jest w stanie wykazać przesłanki gotowości do wykonywania pracy, chociaż pracodawca również nie jest w stanie zapewnić mu pracy.

\section{Przestój ekonomiczny}

W orzecznictwie Sądu Najwyższego utrwalił się pogląd, zgodnie z którym u podłoża przestoju w rozumieniu art. 81 k.p. nie mogą leżeć przyczyny ekonomiczne, jak zmniejszenie popytu na wyroby (uchwała Sądu Najwyższego z dnia 16 października 1992 roku, I PZP 58/92, OSNCP 1993, nr 6, poz. 95; Walczak 2020, art. 81 k.p., teza B.4). W takim przypadku mamy bowiem do czynienia z ryzykiem gospodarczym pracodawcy (Pisarczyk 2008, s. 28-29; Żołyński 2018, s. 37). Ponadto przepisy szczególne wyróżniają tak zwany przestój ekonomiczny, w łagodzeniu skutków którego przewidziana jest pewna forma pomocy państwa. Takie rozwiązania znajdowały się w ustawie z dnia 1 lipca 2009 
roku o łagodzeniu skutków kryzysu ekonomicznego dla pracowników i przedsiębiorców (Dz.U. 2009, nr 125, poz. 1035 ze zm., dalej: ustawa o łagodzeniu skutków kryzysu ekonomicznego, ł.s.k.e.). Obecnie znajdują się w ustawie z dnia 11 października 2013 roku o szczególnych rozwiązaniach związanych z ochroną miejsc pracy (Dz.U. 2019, poz. 669 tekst jedn., dalej: s.r.z.o.m.p.). Rozwiązania w tym samym kierunku przewiduje także art. $15 \mathrm{~g}, 15 \mathrm{gg}, 15 \mathrm{zzb}$ aktualnej ustawy w ramach rządowego pakietu tak zwanej tarczy antykryzysowej (ustawa z dnia 2 marca 2020 roku o szczególnych rozwiązaniach związanych z zapobieganiem, przeciwdziałaniem i zwalczaniem COVID-19, innych chorób zakaźnych oraz wywołanych nimi sytuacji kryzysowych, Dz.U. 2020, poz. 374).

Pojęcie przestoju ekonomicznego po raz pierwszy pojawiło się w ustawie o łagodzeniu skutków kryzysu ekonomicznego (Świątkowski 2018, art. 81 k.p., teza V.1). Zgodnie $\mathrm{z}$ definicją zawartą $\mathrm{w}$ art. 2 pkt 8 ł.s.k.e. pracownikowi zatrudnionemu u przedsiębiorcy, który uprzednio w formie pisemnej wyraził zgodę na objęcie go przestojem ekonomicznym, w przejściowych trudnościach finansowych przez łączny okres nie dłuższy niż 6 miesięcy przysługiwało: 1) świadczenie, o którym mowa w art. 14 ust. 1 pkt 1 lit. a, albo stypendium, o którym mowa w art. 24 ust. 1 pkt ł.s.k.e., oraz 2) wynagrodzenie o łącznej wysokości minimalnego wynagrodzenia za pracę ustalonego na podstawie odrębnych przepisów. W okresie pobierania świadczeń stosunek pracy podlegał ochronie przed rozwiązaniem.

W świetle art. 2 pkt 2 s.r.z.o.m.p. przez „przestój ekonomiczny” należy rozumieć „niewykonywanie pracy u przedsiębiorcy w przejściowych trudnościach finansowych przez pracownika pozostającego w gotowości do pracy z przyczyn ekonomicznych niedotyczących pracownika”. Do tej definicji odwołuje się także najnowsza - przytaczana już - specustawa z dnia 2 marca 2020 roku w art. $15 \mathrm{~g}$ ust. 5 .

W każdym przypadku regulacje te jednak nie odnoszą się wprost do samego zjawiska siły wyższej, ale do problemów ekonomicznych pracodawców i ochrony miejsc pracy powstałych w jego następstwie. Dlatego też w zakresie omawianego zagadnienia można je interpretować, moim zdaniem, jedynie jako łagodzenie następstw przestojów powstałych na skutek zjawiska siły wyższej. Ustawa zakłada jednak spełnianie w takich sytuacjach przez pracownika przesłanki „gotowości do wykonywania pracy”.

\section{Podsumowanie}

Ryzyko wypłaty wynagrodzenia przestojowego po stronie pracodawcy nie budzi większych wątpliwości przy przestoju spowodowanym zwykłymi przyczynami organizacyjnymi czy technicznymi. Jednakże obowiązek ten jest, moim zdaniem, znacznie trudniejszy do wytłumaczenia w przypadku przestoju spowodowanego siłą wyższą, a zwłaszcza taką, która występuje po stronie zarówno pracownika, jak i pracodawcy. Powstają wątpliwości dotyczące tego, czy powyższe zawiera się w kategorii ryzyka działalności pracodawcy.

Istnieją także argumenty przemawiające za tezą, iż w przypadku przestoju wywołanego siłą wyższą, która powoduje także niemożność świadczenia pracy leżącą po stronie 
pracownika, w braku regulacji szczególnych (jak na przykład wymienione powodzie czy zdarzenia atmosferyczne) pracownikowi nie przysługują ani wynagrodzenie przestojowe, ani żadne inne świadczenia.

Jeżeliby jednak mimo to przyjąć, iż wynagrodzenie przestojowe wypłacane w sytuacji wystąpienia przestoju na skutek siły wyższej oraz przy jednoczesnej wątpliwej możliwości świadczenia przez samego pracownika pracy (na przykład ze względów administracyjnych) jest należne na mocy art. 81 k.p., to w takim przypadku, moim zdaniem, powinno być ono kwalifikowane jako rodzaj świadczenia społecznego związanego z pracą, a nie w kategorii ryzyka pracodawcy.

Konkludując swoje rozważania, wyrażam pogląd, iż ze względu na istotną odmienność sytuacji faktycznej i prawnej przestój powstały na skutek działania siły wyższej wymaga de lege ferenda odrębnych regulacji. Dotyczy to zwłaszcza przypadku, gdy siła wyższa uniemożliwia wypełnianie zobowiązań przez obie strony stosunku pracy. Polski ustawodawca nie wprowadził generalnego ograniczenia ryzyka pracodawcy w przypadku wystąpienia siły wyższej. Rozwiązania takie występują w ustawodawstwach zagranicznych (Pisarczyk 2008, s. 216-217). Za słuszne uważam pojawiające się w doktrynie postulaty przejęcia w takich sytuacjach kosztów ochrony pracowników przez fundusze gwarancyjne (Pisarczyk 2008, s. 229, 235, 286-287). Dotychczasowa praktyka potwierdza przy tym, że doraźne regulacje w tej materii są wprowadzane przez polskiego ustawodawcę "na szybko", dopiero w przypadku pojawienia się na skalę krajową określonych zdarzeń o charakterze siły wyższej.

\section{Bibliografia}

Goździewicz G. (2009) Refleksje na temat prawa do godziwego wynagrodzenia za prace [w:] W. Sanetra (red.), Wynagrodzenie za prace w warunkach społecznej gospodarki rynkowej i demokracji, Warszawa.

Lackoroński B. (2009) Glosa do wyroku SN z 16 maja 2007 r., III CSK 452/06, OSP 2009, nr 2, poz. 19.

Lewandowicz-Machnikowska M. (2019) [w:] K.W. Baran (red.), Prawo pracy i ubezpieczeń społecznych, wyd. 3, Warszawa.

Machnikowski P. (2019) [w:] E. Gniewek (red.), Kodeks cywilny. Komentarz, wyd. 9, Warszawa, Legalis.

Mędrala M. (2020) Społeczny charakter świadczeń w polskim prawie pracy, wyd. 2, Warszawa.

Muszalski W. (2019) [w:] W. Muszalski (red.), Kodeks pracy. Komentarz, wyd. 12, Warszawa, Legalis.

Nowak M. (2007) Prawo do godziwego wynagrodzenia za pracę. Regulacja prawna i treść, Łódź. Pisarczyk Ł. (2008) Ryzyko pracodawcy, Warszawa.

Skoczyński J. (2005) [w:] Z. Salwa Z. (red.), M. Gersdorf, K. Rączka, J. Skoczyński, Kodeks pracy. Komentarz, LEX. 
Skoczyński J. (2009) Wynagrodzenie za czas przestoju [w:] W. Sanetra (red.), Wynagrodzenie za prace w warunkach społecznej gospodarki rynkowej i demokracji, Warszawa.

Skotnicka M. (2012) Powódź tysiąclecia - wrocławska fala wspomnień, „Pamięć i Przyszłość”, 2(16).

Świątkowski A.M. (2018) Kodeks pracy. Komentarz, wyd. 6, Warszawa, Legalis.

Święcicki M. (1968) Prawo pracy, Warszawa.

Tomaszewska M. (2016) [w:] J. Stelina (red.), Prawo pracy, wyd. 3, Warszawa.

Wagner B. (2017) [w:] L. Florek (red.), Kodeks pracy. Komentarz, wyd. 7, LEX.

Walczak K. (2020) [w:] K. Walczak (red.), Kodeks pracy. Komentarz, wyd. 31, Legalis.

Żołyński J. (2018) Indywidualne, procesowe i zbiorowe prawo pracy, Gdańsk.

\section{Źródła internetowe}

Gotowość [w:] Słownik języka polskiego PWN, https://sjp.pwn.pl/szukaj/przest\%C3\%B3j.html (dostęp: 25 marca 2020).

Przestój [w:] Słownik języka polskiego PWN, https://sjp.pwn.pl/szukaj/gotowo\%C5\%9B\%C4\%87. html (dostęp: 25 marca 2020).

Stanowisko Państwowej Inspekcji Pracy z 12 marca 2020 roku, https://www.pip.gov.pl/pl/ wiadomosci/108610,praca-zdalna-przeciwdzialanie-covid-19.html (dostęp: 24 marca 2020).

\section{Orzecznictwo}

Uchwała Sądu Najwyższego z dnia 19 czerwca 1979 roku, I PZP 20/79, Legalis nr 212070.

Uchwała Sądu Najwyższego z dnia 16 października 1992 roku, I PZP 58/92, OSNCP 1993, nr 6, poz. 95.

Wyrok Sądu Najwyższego z dnia 3 czerwca1998 roku, I PKN 49/98, OSNAPiUS 1999, nr 11, poz. 362.

Wyrok Sądu Najwyższego z dnia 26 czerwca 1998 roku, I PKN 195/98, OSNAPiUS 1999, nr 14, poz. 453.

Wyrok Sądu Najwyższego z dnia 14 maja 1999 roku, I PKN 60/99, OSNAPiUS 2000, nr 15, poz. 5.

Wyrok Sądu Najwyższego z dnia 2 września 2003 roku, I PK 345/02, OSNP 2004, nr 18, poz. 308.

Wyrok Sądu Najwyższego z dnia 4 grudnia 2003 roku, I PK 109/03, OSNP 2004, nr 21, poz. 367.

Wyrok Sądu Najwyższego z dnia 19 maja 2004 roku, I PK 486/03, Legalis nr 67895.

Wyrok Sądu Najwyższego z dnia 23 września 2004 roku, I PK 541/03, OSNP 2005, nr 7, poz. 94.

Wyrok Sądu Najwyższego z dnia 11 stycznia 2006 roku, II PK 111/05, OSNP 2006, nr 23-24, poz. 347.

Wyrok Sądu Najwyższego z dnia 23 października 2006 roku, I PK 110/06, Legalis nr 79155.

Wyrok Sądu Najwyższego z dnia 16 maja 2007 roku, III CSK 452/06, OSP 2009, nr 2, poz. 19.

Wyrok Sądu Najwyższego z dnia 20 lipca 2007 roku, I CK 3/07, OSNC-ZD 2008, nr 3, poz. 65.

Uchwała Sądu Najwyższego z dnia 13 grudnia 2007 roku, III CZP 100/07, OSNC 2008, nr 12, poz. 139.

Wyrok Sądu Najwyższego z dnia 17 stycznia 2008 roku, III CSK 202/07, Legalis nr 127040.

Wyrok Sądu Najwyższego z dnia 14 grudnia 2009 roku, I PK 115/09, Legalis nr 244007. 
Wyrok Sądu Najwyższego z dnia 3 lutego 2016 roku, II PK 339/14, Legalis nr 1421831.

\section{Akty prawne}

Ustawa z dnia 26 czerwca 1974 roku - Kodeks pracy, Dz.U. 2019, poz. 1040 tekst jedn. ze zm. Ustawa z dnia 17 lipca 1997 roku o stosowaniu szczególnych rozwiązań w związku z likwidacją skutków powodzi, która miała miejsce w lipcu 1997 roku, Dz.U. 1997, nr 80, poz. 491 ze zm.

Ustawa z dnia 10 października 2002 roku o minimalnym wynagrodzeniu za pracę, Dz.U. 2002, nr 200, poz. 1679; Dz.U. 2018, poz. 2177 tekst jedn. ze zm.

Ustawa z dnia 13 marca 2003 roku o szczególnych zasadach rozwiązywania z pracownikami stosunków pracy z przyczyn niedotyczących pracowników, Dz.U. 2018, poz. 1969 tekst jedn.

Ustawa z dnia 5 grudnia 2008 roku o zapobieganiu oraz zwalczaniu zakażeń i chorób zakaźnych u ludzi, Dz.U. 2019, poz. 1239 tekst jedn. ze zm.

Ustawa z dnia 1 lipca 2009 roku o łagodzeniu skutków kryzysu ekonomicznego dla pracowników i przedsiębiorców, Dz.U. 2009, nr 125, poz. 1035 ze zm.

Ustawa z dnia 16 września 2011 roku o szczególnych rozwiązaniach związanych z usuwaniem skutków powodzi, Dz.U. 2019, poz. 1317 tekst jedn. ze zm.

Ustawa z dnia 11 października 2013 roku o szczególnych rozwiązaniach związanych z ochroną miejsc pracy, Dz.U. 2019, poz. 669 tekst jedn.

Ustawa z dnia 2 marca 2020 roku o szczególnych rozwiązaniach związanych z zapobieganiem, przeciwdziałaniem i zwalczaniem COVID-19, innych chorób zakaźnych oraz wywołanych nimi sytuacji kryzysowych, Dz.U. 2020, poz. 374.

Rozporządzenie Ministra Zdrowia z dnia 13 marca 2020 roku w sprawie ogłoszenia na obszarze Rzeczypospolitej Polskiej stanu zagrożenia epidemicznego, Dz.U. 2020, poz. 433.

Rozporządzenia Ministra Zdrowia z dnia 20 marca 2020 roku w sprawie ogłoszenia na obszarze Rzeczypospolitej Polskiej stanu epidemii, Dz.U. 2020, poz. 491. 